\title{
Aspek Interoperabilitas Antara Lantamal IX Dengan Kamla Zona Bahari Timur Dalam Penegakan Hukum Di Laut Maluku Ditinjau Dari Perspektif Harmonisasi Hukum
}

\author{
Andrizal ${ }^{1}$, John Dirk Pasalbessy 2, Arman Anwar ${ }^{3}$ \\ 1,2,3 Fakultas Hukum Universitas Pattimura, Ambon, Indonesia. \\ (@) : andrizal2510@gmail.com \\ doi : $x x x x x x x x x x x x x x x x$
}

\begin{tabular}{l}
\hline Info Artikel \\
Keywords: \\
Law Enforcement; \\
Interoperability; \\
Harmonization of Law; \\
LANTAMAL IX; East \\
Maritime Zone; Kamla.
\end{tabular}

Kata Kunci:

Penegakan Hukum;

Interoperabilitas;

\begin{abstract}
Introductioan: The basic conception of the realization of security in the territorial waters essentially has two dimensions, namely the enforcement of sovereignty and the enforcement of security which are interrelated with each other.

Purposes of the Research: This study aims to analyze and discuss the interoperability between Lantamal IX and Kamla of the East Maritime Zone in law enforcement in the Maluku Sea is viewed from the perspective of legal harmonization and the obstacles faced by Lantamal IX and Kamla of the East Maritime Zone in Law Enforcement in the Maluku Sea when interoperability is connected. with efforts to harmonize the law.

Methods of the Research: The research was conducted using a normative juridical method with a c statutory approach, conceptual approach and comparative approach a by specifically analyzing the performance of the institution and its authority in the implementation of law enforcement in the Maluku Sea based on the legislation which was then analyzed qualitatively.

Results of the Research: The results showed that Lantamal IX and Kamla East Maritime Zone had the same authority in conducting security and safety patrols in the Maluku Sea, thus potentially causing overlapping authorities. Therefore, interoperability is needed between the two institutions in order to create synergy and minimize the occurrence of sectoral egos. So far, the interoperability of Lantamal IX and Kamla of the East Maritime Zone has been established, but it has not run optimally and continuously. Functional analysis of the collaboration between LANTAMAL IX and the East Maritime Zone Kamla shows that there are obstacles related to juridical and material aspects. In the juridical aspect, the East Maritime Zone Kamla does not have the authority to investigate so that the ship being considered must be handed over to the authorized agency. In addition, there has been no renewal of the memorandum of understanding between BAKAMLA and TNI Headquarters. As a result, patrol operations are not supported by Indonesian Navy warships. Meanwhile, materially, the facilities and infrastructure of the East Maritime Zone Kamla are minimal while BAKAMLA has a large enough budget for the implementation of operations. Likewise, the synergy of operations and sharing of data and information has not been maximized. Therefore, interoperability is needed through harmonization of law and synergy.
\end{abstract}

\footnotetext{
Abstrak

Latar Belakang: Konsepsi dasar terhadap perwujudan keamanan di wilayah perairan pada hakikatnya memiliki dua dimensi yaitu penegakan kedaulatan dan penegakan keamanan yang saling berkaitan satu sama lainnya.
} 


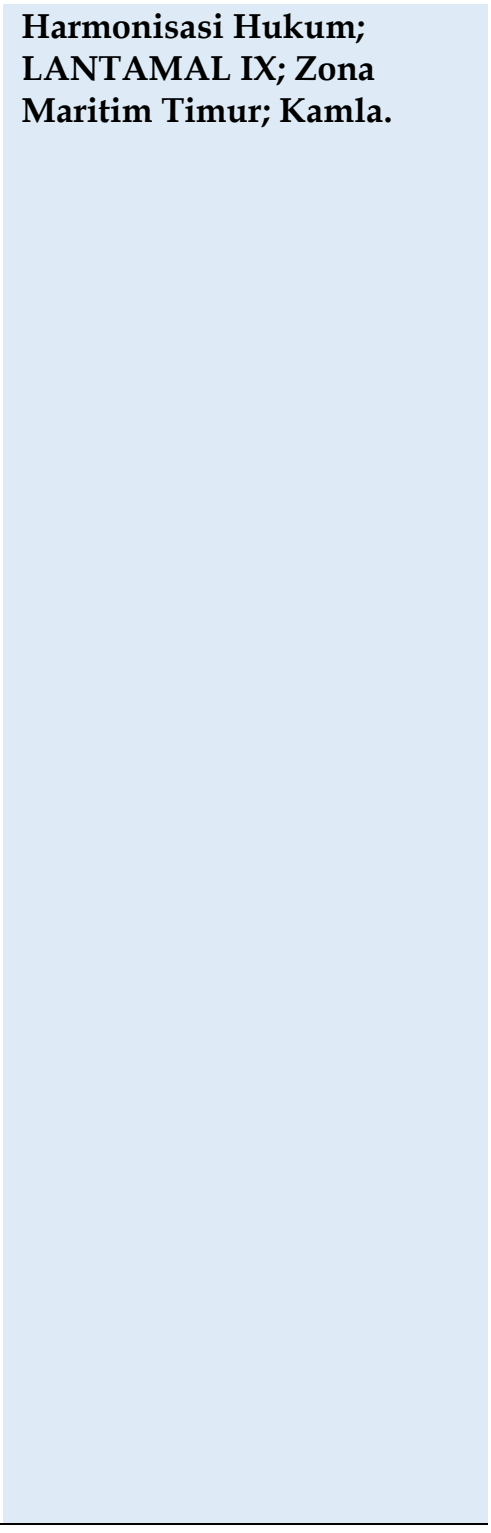

Tujuan Penelitian: Penelitian ini bertujuan untuk menganalisa dan membahas interoperabilitas antara Lantamal IX dengan Kamla Zona Maritim Timur dalam penegakan hukum di Laut Maluku ditinjau dari perspektif harmonisasi hukum serta hambatan yang dihadapi Lantamal IX dan Kamla Zona Maritim Timur dalam Penegakan Hukum di Laut Maluku ketika melakukan interoperabilitas dihubungkan dengan upaya melakukan harmonisasi hukum.

Metode Penelitian: Penelitian menggunakan metode yuridis normatif dengan pendekatan perundang-undangan, pendekatan konseptual dan pendekatan perbandingan hukum dengan menganalisis secara spesifik kinerja institusi dan kewenangannya dalam penyelenggaraan penegakan hukum di laut Maluku berdasarkan peraturan perundang-undangan yang kemudian dianalisis secara kualitatif.

Hasil Penelitian: Hasil penelitian menunjukan bahwa Lantamal IX dan Kamla Zona Maritim Timur memiliki kewenangan yang sama dalam melakukan patroli keamanan dan keselamatan di Laut Maluku sehingga berpotensi menimbulkan tumpang tindih kewenangan. Oleh karena itu, dibutuhkan interoperabilitas diantara kedua institusional dimaksud agar terjadi sinergitas dan meminimalkan terjadinya ego sektoral. Selama ini interoperabiltas Lantamal IX dan Kamla Zona Maritim Timur sudah terbentuk, namun belum berjalan optimal dan kontinyu. Analisa fungsional terhadap kerjasama LANTAMAL IX dan Kamla Zona Maritim Timur menunjukan adanya hambatan terkait aspek yuridis dan meteril. Pada aspek yuridis, Kamla Zona Maritim Timur tidak memiliki kewenangan penyidikan sehingga kapal yang ditanggap harus diserahkan kepada instansi yang berwenang. Selain itu, belum dilakukannya pembaharuan nota kesepahaman antara BAKAMLA dengan Mabes TNI. akibatnya operasi patroli tidak didukung kapal perang TNI AL. Sedangkan secara materil, sarana dan prasarana Kamla Zona Maritim Timur minim kapal sementara BAKAMLA memiliki anggaran yang cukup besar untuk pelaksanaan operasi. Demikianpun sinergitas operasi maupun sharing data dan informasi juga belum maksimal. Oleh sebab itu dibutuhkan interoperabilitas melalui harmonisasi hukum dan sinergitas.

\section{Pendahuluan}

Indonesia adalah negara kepulauan (achipelagic state) terbesar di dunia yang memiliki posisi geografis yang sangat strategis. Jumlah pulau di Indonesia yang resmi tercatat mencapai 16.056 pulau. Kepastian jumlah ini ditentukan dalam forum United Nations Confrences on the Standardization of Geographical Names (UNCSGN) dan United Nations Group of Experts on Geographical Names (UNGEGN) yang berlangsung pada 7-18 Agustus 2017 di New York, Amerika Serikat. ${ }^{1}$ Selain itu, garis pantai Indonesia adalah sepanjang 99.039 $\mathrm{km}^{2}$. Luas daratannya mencapai sekitar 2,012 juta $\mathrm{km}^{2}$ dan laut sekitar 5,8 juta km² $(75,7 \%)$,

${ }^{1}$ Akhyari Hananto, “Dikukuhkan Di New York Agustus Ini, Inilah Jumlah Resmi Pulau Di Indonesia," www.goodnewsfromindonesia.id, https://www.goodnewsfromindonesia.id/2017/08/19/dikukuhkan-di-new-york jumlah-resmi-pulau-di-indonesia. 
2,7 juta $\mathrm{km}^{2}$ diantaranya termasuk dalam Zona Ekonomi Ekslusif (ZEE), ${ }^{2}$ sehingga timbul suatu keamanan dan ketertiban di ZEE dengan otomatis kepentingan khusus negara pantai bisa terlindungi dan diharapkan semua negara bisa bekerja sama dalam menjaga kelestarian ekosistem laut sekaligus menjaga keamanan pelayaran di laut sehingga dapat tercipta suatu hubungan internasional yang baik antar negara, khususnya di bidang kemaritiman $^{3}$. Laut Indonesia yang sangat luas 2,5 kali lipat dari wilayah daratan pastinya memiliki potensi yang sangat besar, baik dari segi kekayaan alam maupun jasa lingkungan yang dapat dimanfaatkan untuk mendukung pembangunan ekonomi pada tingkat lokal, regional, dan nasional.

Perairan Maluku sebagai rangkuman zona limitasi akan memainkan peranan penting dalam jalur perdagangan, maka dari itulah Alur Laut Kepulauan Indonesia III (ALKI III) yang melintasi samudera pasifik, laut maluku, laut seram, laut banda, selat ombai, dan laut sawu benar-benar dipersiapkan dari segi sarana dan infrastruktur. Hal ini akan membangkitkan geliat perdagangan melalui samudera pasifik dan menjadi pilihan rasional yang potensial untuk Indonesia kedepan, aspek geopolitik dan geostrategis sangat menunjang posisi Indonesia sebagai penghubung (port) dari pasifik ke negara-negara Asia Tenggara dan juga ke Asia Selatan dengan tetap menjamin keberlangsungan rute dagang internasional selat malaka meskipun terusan Kra sudah beroperasi. ${ }^{4}$

Letak geografis perairan Maluku baik di selatan maupun di utara sama-sama berpotensi sebagai penghubung regional dimana kota-kota pentingnya sangat prospektif untuk dijadikan sebagai kota-kota pelabuhan internasional, misalnya Ternate dan Morotai di utara yang dapat memegang kendali pada koridor utara trans-pasifik dan menjadi penghubung antara Australia-Selandia Baru dengan Filipina serta negara-negara seperti Chili, Meksiko, Peru, Amerika Serikat dan negara-negara kecil di Samudera Pasifik dengan Jepang, Korea, bahkan Cina. Di sisi lain, dinamika kebudayaan telah menjamin kesiapan dalam menyongsong era pasifik, identitas orang-orang kepulauan Maluku sebagai masyarakat maritim yang ditempa oleh sejarah yang berhubungan dengan perdagangan laut selama berabad-abad adalah suatu keunggulan yang tidak dapat dinafikkan. ${ }^{5}$

Sehubungan dengan Indonesia sebagai negara kepulauan terbesar di dunia, sehingga pastinya Indonesia berpotensi menjadi poros maritim dunia. Poros maritim dunia bertujuan menjadikan Indonesia sebagai negara maritim yang besar, kuat, dan makmur melalui pengembalian identitas Indonesia sebagai bangsa maritim untuk mewujudkan pemerataan ekonomi Indonesia. Negara poros maritim dunia harus diliputi dengan pembangunan proses maritim dari aspek infrastruktur, politik, sosial-budaya, hukum, keamanan, dan ekonomi. Penegakan kedaulatan laut Indonesia, revitalisasi sektor-sektor ekonomi kelautan, penguatan dan pengembangan konektivitas maritim, rehabilitasi kerusakan

2 Muhammad Ramdhan and Taslim Arifin, "Aplikasi Sistem Informasi Geografis Dalam Penilaian Proporsi Luas Laut Indonesia," Jurnal Ilmiah Geomatik 19, no. 2 (2013): 141-46.

${ }^{3}$ Zainal Abdul Aziz Hadju, "Analisis UNCLOS 1982 Terkait Permasalahan Yurisdiksi Negara Dan Penegakan Hukum Atas Kapal Berbendera Negara Asing," SASI 27, no. 1 (2021): 12-23, https://doi.org/10.47268/sasi.v27i1.254.

4 Jamaludin Rumata, "Kepulauan Maluku Dalam Geopolitik Regional," kompastimur.com, 2018, https://www.kompastimur.com/2018/10/kepulauan-maluku-dalam-geopolitik.html.

${ }^{5}$ Ibid. 
lingkungan dan konservasi biodiversity, serta peningkatan kualitas dan kuantitas SDM kelautan, merupakan program-program utama dalam upaya mewujudkan Indonesia sebagai poros maritim dunia.

Dalam mewujudkan Indonesia sebagai poros maritim dunia, Pemerintah mencanangkan lima pilar utama dalam mewujudkan cita-cita Indonesia sebagai poros maritim dunia, yaitu:

1) Pilar pertama: Pembangunan kembali budaya maritim Indonesia;

2) Pilar kedua: Berkomitmen dalam menjaga dan mengelola sumber daya laut dengan fokus membangun kedaulatan pangan laut melalui pembangunan industri perikanan dengan menempatkan nelayan sebagai pilar utama;

3) Pilar ketiga: Komitmen mendorong pengembangan infrastruktur dan konektivitas maritim dengan membangun tol laut, pelabuhan laut, logistik, dan industri perkapalan serta pariwisata maritim;

4) Pilar keempat: Diplomasi maritim yang mengajak semua mitra Indonesia untuk bekerjasama pada bidang kelautan;

5) Pilar kelima: Membangun kekuatan pertahanan maritim. ${ }^{6}$

Dengan posisi Indonesia yang sangat strategis, menjadikan wilayah perairan Indonesia dilewati oleh oleh jalur utama kapal-kapal laut dari berbagai negara, baik kapalkapal dagang maupun kapal-kapal angkatan laut dari berbagai negara di dunia. Pasal 50 Undang-Undang Nomor 32 Tahun 2014 tentang Kelautan (selanjutnya disebut UU Kelautan) memberikan amanah kepada Pemerintah untuk melakukan upaya perlindungan lingkungan laut melalui:

a) konservasi laut;

b) pengendalian pencemaran laut;

c) penanggulangan bencana kelautan; dan

d) pencegahan dan penanggulangan pencemaran, kerusakan dan bencana.

Dengan banyaknya potensi yang dapat digali dari wilayah perairan di Indonesia, maka tentu saja hal ini akan memberikan dampak yang tidak dapat terelakkan, yaitu akan munculnya ancaman terhadap kepentingan Indonesia, khususnya dalam bidang kemaritiman. Ancaman kemaritiman tersebut dapat dibagi menjadi 2, yaitu ancaman terhadap keamanan wilayah dan ancaman terhadap kelestarian sumberdaya kelautan Indonesia. Ancaman tersebut dapat berasal dari berbagai sumber, baik dari negara tertentu maupun aktor non-negara, dengan intensitas ancaman yang beragam pula. Dengan kenyataan akan munculnya beberapa ancaman tersebut, maka Indonesia perlu menanggapinya dengan kemampuan dan kekuatan keamanan maritime yang memadai, agar berbagai ancaman tersebut dapat ditekan seminimal mungkin. Namun telah disadari bersama bahwa penyelenggaraan kemanan maritim tidaklah mudah, karena memerlukan

${ }^{6}$ Kementerian Komunikasi dan Informatika Republik Indonesia, Menuju Poros Maritim Dunia, https://www.kominfo.go.id/content/detail/8231/menuju-poros-maritim-dunia/0/kerja_nyata, diakses pada tanggal 13 Maret 2020 
penataan atau governance yang sistematis, serta pengaturan atau manajemen yang baik pula. ${ }^{7}$

Data statistik sepanjang tahun 2011 sampai dengan 2015 jumlah tindak pidana perikanan sebanyak 512 dengan berbagai jenis tindak pidana, yang berupa tanpa ijin, menangkap terlarang, dokumen tidak lengkap, alat tangkap terlarang, alat tangkap tidak sesuai ijin, dan sebagainya. ${ }^{8}$ Sedangkan dalam sepanjang tahun 2019 Korps Polisi Air dan Udara (Korpolairud) Baharkam Polri merilis ada 442 tindak kejahatan di laut yang telah ditangani. Dari 442 tersebut, 191 kapal ikan, baik asing maupun lokal diproses hukum karena diduga melakukan illegal, unreported, unregulated fishing (IUUF) atau penangkapan ikan secara ilegal sepanjang tahun 2019. ${ }^{9}$ Selain itu sepanjang tahun 2019 penyelundupan narkotika ke Indonesia sebanyak 90\% melewati jalur laut, sehingga laut dianggap sebagai jalur favorit untuk penyelundupan narkotika. Dari data penyelundupan jalur laut, jumlah narkotika yang diselundupkan dengan jumlah yang fantastis. Terdapat 6 kasus dalam kurun waktu 12 bulan terakhir di mana narkotika disita dalam jumlah kisaran 1 ton, dan kasus tersebut diduga ada kaitannya dengan jaringan narkotika di Indonesia. ${ }^{10}$ Di sisi lain, terdapat kejahatan lain di laut yaitu perompakan. Sepajang tahun 2019, sudah terjadi 31 satu kasus perompakan di selat malaka yang terletak di perbatasan Malaysia dan Pulau Sumatera Indonesia. ${ }^{11}$

Dengan diundangkannya UU Kelautan memberikan amanat tentang munculnya lembaga baru yang disebut dengan Badan Keamanan Laut (BAKAMLA) yang menggantikan Badan Koordinasi Keamanan Laut (BAKORKAMLA). Kemudian kedudukan BAKAMLA semakin diperkuat dengan diterbitkannya Peraturan Presiden Nomor 178 Tahun 2014 tentang Badan Keamanan Laut (selanjutnya disebut PERPRES 1278/2014).Selanjutnya, Pasal 59 ayat (3) UU Kelautan menyatakan: “Dalam rangka penegakan hukum di wilayah perairan dan wilayah yuridiksi, khususnya dalam melaksanakan patrol keamanan dan keselamatan di wilayah perairan dan wilayah yurisdiksi Indonesia, dibentuk Badan Keamanan Laut"

Pasal 61 UU Kelautan memberikan tugas kepada BAKAMLA untuk melakukan patrol kemanan dan keselamatan di wilayah laut perairan Indonesia dan wilayah yurisdiksi Indonesia. Selain itu, Pasal 62 UU Kelautan, BAKAMLA dalam melaksanakan tugasnya menyelenggarakan fungsi:

7 Syaiful Anwar, "Membangun Keamanan Maritim Indonesia Dalam Analisa Kepentingan, Ancaman, Dan Kekuatan Laut," Jurnal Pertahanan \& Bela Negara 6, no. 3 (2018): 69-90.

8 Badan Pusat Statistik, Statistik Sumber Daya Laut dan Pesisir, https://media.neliti.com/media/publications/48274-ID-statistik-sumber-daya-laut-dan-pesisir-2016.pdf, diakses pada tanggal 17 Maret 2020

9 Audrey Santoso, Polairud Tangkap 442 Tindak Kejahatan di Laut Selama 2019, https:// news.detik.com/berita/d-4842071/polairud-ungkap-442-tindak-kejahatan-di-laut-selama-2019, diakses pada tanggal 17 Maret 2020

10 Fathurrohman, Menjaga Laut Indonesia Dari Narkoba, https://nasional.kompas.com/read/2018/09/23/12234341/menjaga-laut-indonesia-dari-narkoba, diakses pada tanggal 21 Maret 2020

11 Sisweanto Rusdi, Sepanjang 2019 Ada 31 Kasus Perompakan Kapal di Selat Malaka, Bagaimana Peran Indonesia?, http://www.indonesiashippingline.com/wacana-opini/5097-sepanjang-2019-ada-31-kasusperonpakan-kapal-di-selat-malaka,-bagaimana-' peran'-indonesia.html, diakses pada tanggal 21 Maret 2020 
a) menyusun kebijakan nasional di bidang keamanan dan keselamatan di wilayah perairan Indonesia dan wilayah yurisdiksi Indonesia;

b) menyelenggarakan sistem peringatan dini keamanan dan keselamatan di wilayah perairan Indonesia dan wilayah yurisdiksi Indonesia;

c) melaksanakan penjagaan, pengawasan, pencegahan, dan penindakan pelanggaran hukum di wilayah perairan Indonesia dan wilayah yurisdiksi Indonesia;

d) menyinergikan dan memonitor pelaksanaan patroli perairan oleh instansi terkait;

e) memberikan dukungan teknis dan operasional kepada instansi terkait;

f) memberikan bantuan pencarian dan pertolongan di wilayah perairan Indonesia dan wilayah yurisdiksi Indonesia; dan

g) melaksanakan tugas lain dalam sistem pertahanan nasional.

Semakin bertambahnya kapal asing yang tidak dilengkapi dokumen yang ditangkap di wilayah perairan Indonesia yang melakukan tindakan ilegal, hal tersebut memberikan bukti bahwa tindak kejahatan terhadap sumber daya alam yang dimiliki bangsa Indonesia masih belum menunjukkan adanya tanda-tanda penurunan. Selain itu, masih belum efektifnya dalam pelaksanaan pengamanan di wilayah laut, merupakan salah satu kendala yang dihadapi dalam penanganan tindak kejahatan terhadap kekayaan sumber daya alam.Permasalahan pokok yang menjadi perhatian penting hingga kini, adalah tumpah tindih mengenai kewenangan yang ada, seperti halnya antara Tentara Negara Indonesia Angkatan Laut (selanjutnya disebut TNI AL) dan BAKAMLA dalam menangani kasus pelanggaran yang terjadi diwilayah perairan Indonesia.

TNI AL sebagai komponen utama pertahanan negara di wilayah perairan berkewajiban untuk menjaga kedaulatan negara dan integritas wilayah Indonesia, mempertahankan stabilitas keamanan di wilayah perairan, melindungi sumber daya alam di wilayah perairan dari berbagai bentuk gangguan keamanan dan pelanggaran hukum di wilayah perairan yuridiksi nasional Indonesia. Konsepsi dasar terhadap perwujudan keamanan di wilayah perairan pada hakikatnya memiliki dua dimensi yaitu penegakan kedaulatan dan penegakan keamanan yang saling berkaitan satu sama lainnya ${ }^{12}$.

TNI AL di dalam pelaksanaan tugas pokoknya, harus mengacu pada tugas pokok TNI AL sesuai yang termaktub didalam Pasal 9 Undang-undang RI Nomor 34 tahun 2004 tentang Tentara Nasional Indonesia (selanjutnya disebut UU TNI) diantaranya adalah:

1) Melaksanakan tugas TNI matra laut di bidang pertahanan;

2) Menegakkan hukum dan menjaga kemanan di wilayah laut yurisdiksi nasional sesuai dengan ketentuan hukum nasional dan hukum internasional;

3) Melaksanakan tugas diplomasi Angkatan Laut dalam rangka mendukung kebijakan politik luar negeri yang ditetapkan oleh Pemerintah;

4) Melaksanakan tugas dan pengembangan kekuatan matra laut;

5) Melaksanakan pemberdayaan wilayah pertahanan laut.

${ }^{12}$ Lucia Charlota Octovina Tahamata, "Penegakan Hukum Diwilayah Laut Maluku Oleh Lantamal IX Ambon," Balobe Law Journal 1, no. 1 (2021): 17-24. 
Didalam kegiatan tindak pengamanan wilayah laut atau maritim, tidak hanya terkait dengan penegakan hukum di wilayah laut saja, akan tetapi termasuk wilayah luas yang aman untuk dipergunakan bagi pengguna dan harus bebas dari bentuk-bentuk ancaman atau gangguan terhadap aktifitas penggunaan dan pemanfaatan sumber daya laut, ${ }^{13}$ dalam kaitannya kerjasama antar lembaga dengan prinsip good governance di dalam TNI AL dan BAKAMLA sebenarnya kerjasama antara BAKAMLA dengan TNI AL sudah dilaksanakan, namun masih terdapat beberapa kendala diantaranya adalah belum adanya pembaharuan Nota Kesepahaman antara BAKAMLA dengan Mabes TNI yang ditandatangani oleh masing-masing pejabat yang masih eksis, yang ada adalah Nota Kesepahaman tahun 2015, pada saat KaBAKAMLA dijabat oleh Laksamana Madya TNI Dr D.A Mamahit MSc dan Panglima TNI dijabat oleh Jenderal TNI Dr. Moeldoko. Adapun ruang lingkup Nota Kesepahaman tersebut meliputi: 1) Penyelenggaraan Operasi Keamanan dan Keselelamatan di Laut, 2) Penggunaan Sarana dan Prasarana, 3) Pendidikan dan Latihan, 4) Pertukaran data dan informasi yang diperlukan, 5) Penugasan Personel. Masa berlaku Nota Kesepahaman tersebut adalah lima tahun sejak ditandatangani kedua belah pihak.

Penggunaan Alat Utama Sistim Senjata/Alutsista TNI termasuk kapal perang TNI AL dan pesawat Maritime Patrol Aircraf/MPA TNI AU harus Panglima TNI), kecuali kapal klasifikasi KAL. Oleh karena itu, pada saat kedua pejabat tersebut masih menjabat, maka permohonan penggunaan Alutsista TNI baik KRI maupun pesawat TNI AU olah BAKAMLA segera mendapat persetujuan dari Panglima TNI. Namun sejak adanya pergantian Panglima TNI dari Jenderal TNI Dr. Moeldoko kepada Jeneral TNI Gatot Nurmantyo, maka beberapa kali permohonan dukungan kapal TNI AL (KRI) dan pesawat TNI AU untuk melaksanakan kegiatan patroli maritime tidak mendapat dukungan hingga operasi berakhir. Tidak didukungnya permohonan tersebut sangat dimungkinkan bahwa Panglima memiliki pertimbangan dan kebijakan sendiri terkait hal tersebut.

Untuk itu sangatlah penting untuk dapat memahami sistem keamanan laut dengan baik, dengan tujuan untuk menciptakan sistem pendekatan yang bersifat komprehensif serta bersifat integral didalam proses penanganannya. Salah satu topik keamanan laut atau maritim yang menjadi perhatian cukup besar pada masa sekarang ini yaitu terkait dengan tindakan kejahatan atau ilegal di wilayah perairan Indonesia. Tindak kejahatan yang dilakukan di wilayah perairan Indonesia justru semakin marak, kegiatan ilegal yang dilakukan telah meningkat baik dalam lingkup intensitas dan kompleksitasnya sehingga sudah sangat mengancam kondisi sosial, ekonomi dan politik negara Indonesia serta diwilayah kawasan yang ada disekitarnya. ${ }^{14}$

\section{Metode Penelitian}

Penelitian ini adalah penelitian yuridis normatif yaitu penelitian yang difokuskan untuk mengkaji penerapan kaidah-kaidah atau norma-norma dalam hukum positif. ${ }^{15}$ Yuridis Normatif, yaitu pendekatan yang menggunakan konsepsi legis positivis. Konsep ini

${ }^{13}$ Heru Wiratama, “Kewenangan TNI AL Selaku Penyidik Tindak Pidana Dilaut Dalam Mengamankan Perairan Indonesia," Jurnal Hukum, 2015, 1-30.

${ }^{14}$ Ibid, h. 8

15 Johnny Ibrahim, Teori Dan Metode Penelitian Hukum Normatif (Malang: Malang: Bayu Media Publishing, 2006), h. 285. 
memandang hukum identik dengan norma-norma tertulis yang dibuat dan diundangkan oleh lembaga atau pejabat yang berwenang. Konsepsi ini memandang hukum sebagai suatu sistem normatif yang bersifat mandiri, tertutup dan terlepas dari kehidupan masyarakat yang nyata ${ }^{16}$, dalam definisi yang singkat, Penelitian Hukum Normatif atau disebut juga penelitiuan hukum kepustakaan adalah: "Penelitian hukum yang dilakukan dengan cara meneliti bahan pustaka atau data sekunder belaka" ${ }^{17}$ Menurut Piter Mahmud Marzuki Penelitian hukum normative merupakan proses untuk menemukan aturan hukum, prinsipprinsip hukum, maupun doktrin-doktrin hukum guna menjawab isu hukum yang dihadapi. Penelitian ini, terutama mengkaji ketentuan-ketentuan hukum positif maupun asas-asas hukum yang bertujuan untuk mencari pemecahan atas isu hukum serta permasalahan yang timbul didalamnya, sehingga hasil yang akan dihadapi kemudian adalah memberikan preskripsi mengenai apa yang ada atas isu yang diajukan. ${ }^{18}$

\section{Hasil dan Pembahasan}

\subsection{Interoperabilitas Lantamal IX dan KAMLA Zona Maritim Timur Dalam Penegakan Hukum di Laut Maluku}

Secara yuridis formal, berdasarkan berbagai peraturan perundang-undangan yang berlaku, khususnya yang mengatur mengenai Tentara Nasional Indonesia (selanjutnya disingkat TNI), wilayah perairan laut Indonesia, maupun mengenai tindak pidana tertentu di wilayah perairan laut Indonesia, bahwa TNI AL memiliki tugas dan wewenang untuk melakukan penegakan hukum di wilayah perairan laut Indonesia yang terbatas dalam lingkup pengejaran, penangkapan, penyelidikan, dan penyidikan yang selanjutnya diserahkan kepada kejaksaan untuk dilakukan proses penuntutan. Hal ini sebagaimana dinyatatakan dalam penjelasan Pasal 9 huruf b UU TNI. Selain itu, hal ini juga semakin dipertegas dalam Pasal 17 Peraturan Pemerintah Nomor 27 Tahun 1983 tentang Pelaksanaan Kitab Undang-Undang Hukum Acara Pidana (selanjutnya disingkat PP 27/1983) beserta penjelasannya yang menyatakan:

“Penyidikan menurut ketentuan khusus acara pidana sebagaimana tersebut pada Undang-Undang tertentu sebagaimana dimaksud dalam Pasal 284 ayat (2) KUHAP dilaksanakan oleh penyidik, jaksa, dan pejabat penyidik yang berwenang lainnya berdasarkan peraturan perundang-undangan".

PenjelasanPasal 17:

“Wewenang penyidikan dalam tindak pidana tertentu yang diatur secara khusus oleh undang-undang tertentu dilakukan oleh penyidik, jaksa dan pejabat penyidik lainnya yang ditunjuk berdasarkan peraturan perundang-undangan. Bagi penyidik dalam Perairan Indonesia, zona tambahan, Landas Kontinen dan Zona Ekonomi h. 13-14.

${ }^{16}$ Ronny Hanitijo Soemitro, Metodologi Penelitian Hukum Dan Jurimetri (Jakarta: Ghalia Indonesia, 1990),

17 Soerjono Soekanto and Sri Mamudji, Penelitian Hukum Normatif, Suatu Tinjauan Singkat, Jakarta : Raja Grafindo Persada (Jakarta: Rajawali Pers, 2015), h. 13-14.

18 Peter Mahmud Marzuki, Penelitian Hukum, (Jakarta: Kencana, 2016), https:/ /doi.org/340.072. h. 35. 
Ekslusif Indonesia, penyidikan dilakukan oleh Perwira TNI AL dan pejabat penyidik lainnya yang ditentukan oleh undang-undang yang mengaturnya".

Dengan demikian secara yuridis formal, kewenangan TNI AL dalam melakukan penegakan hukum di wilayah perairan laut Indonesia tidak perlu diragukan lagi. Sesuai dengan ketentuan hukum serta dengan mengingat tugas dari pada TNI AL khususnya dalam bidang penegakan hukum, maka TNI AL sangat berkewajiban, berkepentingan, dan melaksanakan serta melakukan penegakan hukum di wilayah perairan laut Indonesia guna menciptakan keamanan dan ketertiban. ${ }^{19}$

Pasal 9 UU TNI telah disebutkan dengan jelas mengenai tugas pokok TNI AL. Apabila di fokuskan pada tugas TNI AL pada poin-poin diatas maka usaha menegakkan hukum dan menjaga keamanan di laut yurisdiksi nasional adalah segala bentuk kegiatan yang berhubungan dengan penegakan hukum di laut sesuai dengan kewenangan TNI AL (constabulary function) yang berlaku secara universal dan sesuai dengan ketentuan peraturan perundang-undangan yang berlaku untuk mengatasi ancaman tindakan kekerasan, ancaman navigasi, serta pelanggaran hukum di wilayah perairan laut yurisdiksi nasional. Dengan demikian tugas pokok TNI AL selain bidang pertahanan di laut juga menyelenggarakan keamanan laut bagi penggunanya. Pelaksanaan tugas TNI AL dalam bidang keamanan laut, tidak hanya terfokus pada penegakan hukum di laut, karena keamanan laut mengandung pengertian bahwa laut bias dikendalikan dan aman digunakan oleh pengguna untuk bebas dari ancaman atau gangguan terhadap aktifitas pemanfaatan laut. Pertama, laut bebas dari ancaman tersebut dapat berupa, pembajakan perompakan, sabotase, maupun aksi terror bersenjata. Kedua, laut bebas dari ancaman navigasi, yang ditimbulkan dari kondisi geografi dan hidrografi serta kurang memadainya sarana bantu navigasi sehingga membahayakan keselamatan pelayaran. Ketiga, laut bebas dari ancaman terhadap sumber daya laut berupa pencemaran dan perusakan ekosistem laut serta eksploitasi dan eksplorasi berlebihan. Keempat, laut bebas dari ancaman pelanggaran hukum, baik hukum nasional maupun hukum internasional seperti illegal fishing, illegal loging, illegal migrant, penyelundupan dan lain-lain. ${ }^{20}$

Selain itu, di sisi lain dalam hal penegakan hukum di wilayah perairan laut Indonesia juga terdapat Badan Keamanan Laut (selanjutnya disingkat BAKAMLA). Berdasarkan Pasal 61 Undang-Undang Nomor 32 Tahun 2014 tentang Kelautan (untuk selanjutnya disingkat UU Kelautan) menyebutkan bahwa tugas BAKAMLA adalah melakukan patroli keamanan dan keselamatan di wilayah perairan Indonesia dan wilayah yurisdiksi Indonesia. Jika ditinjau dari luasnya wilayah maka tugas BAKAMLA sangat luas yakni melakukan patrol keamanan dan keselamatan di wilayah perairan Indonesia dan wilayah yurisdksi Indonesia. ${ }^{21}$

${ }^{19}$ Wiratama, "Kewenangan TNI AL Selaku Penyidik Tindak Pidana Dilaut Dalam Mengamankan Perairan Indonesia." Op. Cit. h. 13.

${ }^{20} \mathrm{Ibid}, \mathrm{hl} .14$

${ }^{21}$ Gentur Wasisto, "Kewenangan BAKAMLA Dalam Penegakan Hukum Tindak Pidana Tertentu Di Laut Berdasarkan UU No. 32 Tahun 2014 Tentang Kelautan," Jurnal Hukum, 2015, 1-23. 
Menurut Pasal 3 ayat (1) Undang-Undang Nomor 6 Tahun 1996 tentang Perairan (selanjutnya disingkat UU Perairan) yang dimaksud dengan wilayah perairan Indonesia adalah meliputi:

1) Laut teritorial Indonesia;

2) Perairan kepulauan;

3) Perairan pedalaman.

Selain dari perairan yang telah disebutkan di atas, berdasarkan Pasal 3 ayat (2) UU Perairan juga menyebutkan bahwa Indonesia juga mempunyai hak-hak berdaulat atau kedaulatan terbatas, yaitu:

1) Perairan zona tambahan (contiguous zone);

2) Perairan di atas landas kontinen;

3) Perairan zona ekonomi ekslusif.

Jika dicermati kembali, berdasarkan Pasal 61 UU Kelautan maka tugas BAKAMLA sangatlah luas, namun tugas yang demikian belum luas jika belum dilengkapi dengan sarana dan prasarana patroli yang memadai. Kapal patroli BAKAMLA berukuran kecil yang hanya mampu melaksanakan patroli di laut teritorial dan belum mampu menjangkau sampai perairan laut lepas maupun Zona Ekonomi Eksulusif Indonesia (ZEEI). Padahal pada kenyataan normatifnya, laut lepas dan ZEEI merupakan tanggung jawab BAKAMLA untuk harus dijaga keamanannya.

Tugas BAKAMLA terkait dengan menjaga keamanan dan keselamatan yang mungkin terjadi di laut dan perlu di waspadai antara lain:

1) Adanya ancaman terhadap tindakan kekerasan, yaitu ancaman dengan menggunakan kekuatan bersenjata yang terorganisir yang mempunyai kemampuan untuk menggangu serta membahayakan baik personel maupun material serta ancaman terhadap negara. Ancaman tersebut dapat berupa ancaman pembajakan, ancaman terhadap adanya perompakan, ancaman terhadap kegiatan sabotase obyek vital nasional di laut, ancaman adanya penyebaran ranjau dan ancaman terjadinya aksiteror di laut.

2) Ancaman terhadap bahaya navigasi, yaitu ancaman yang ditimbulkan oleh kondisi geografi dan hidrografi serta kurang memadainya sarana dan alat bantu navigasi, antara lain seperti suar, buoy dan lain-lain yang tidak berfungsi sebagaimana mestinya, sehingga dapat membahayakan kesalamatan pelayaran.

3) Ancaman terhadap perusakan sumber daya laut, yakni berupa pencemaran laut dan perusakan ekosistem laut, serta adanya konflik pengelolaan sumber daya laut, sehingga memiliki kecenderungan mudah dipolitisasi dan selanjutnya akan diikuti dengan penggelaran kekuatan militer, misalnya dalam sengketa kepulauan dan sengketa perbatasan.

4) Ancaman terhadap pelanggaran hukum, yaitu kegiatan yang dilakukan secara melanggar ketentuan peraturan perundag-undangan yang berlaku baik perundang-undangan secara nasional maupun internasional, jenis pelanggaran yang sering dilakukan antara lain ancaman terhadap kegiatan illegal fishing, 
ancaman terhadap illegal loging, ancaman terhadap tindak penyelundupan dan berbagai bentuk pelanggaran lainnya.

Pasal 64 UU Kelautan menyebutkan bahwa kebijakan nasional di bidang keamanan dan keselamatan di wilayah Perairan Indonesia dan wilayah yurisdiksi Indonesia sebagaimana dimaksud dalam Pasal 62 huruf a ditetapkan oleh Presiden. Namun hingga saat ini ketetapan Presiden yang dimaksud belum keluar, hal ini akan sangat berpengaruh terhadap BAKAMLA. Demikian juga dengan tugas BAKAMLA dalam hal menjaga keselamatan, belum dijelaskan secara tegas apa yang dimaksud dengan keselamatan. Ada beberapa maksud dengan frasa menjaga keselamatan, yaitu: ${ }^{22}$

1) Jika maksud menjaga keselamatan adalah menjaga keselamatan jiwa di laut maka BAKAMLA harusnya berkiblat pada ketentuan International Maritime Organization (IMO) yakni tentang Safety of Life at Sea (SOLAS);

2) Jika maksud dari menjaga keselamatan adalah melaksanakan SAR maka Ketetapan Presiden hendaknya tidak boleh bertentangan dan harus selaras dengan fungsi BASARNAS;

3) Jika maksud menjaga keselamatan terkait dengan keselamatan pelayaran, maka Ketetapan Presiden hendaknya harus selaras dengan UU Nomor 17 Tahun 2008 tentang Pelayaran (selanjutnya disingkat UU Pelayaran), karena UU Pelayaran ini mengatur tentang perambuan dan navigasi yang menjadi tanggung jawab Kementerian Perhubungan dalam hal ini Perhubungan Laut.

Dalam Pasal 63 ayat (2) UU Kelautan menyebutkan bahwa kewenangan sebagaimana yang dimaksud pada ayat (1) dilaksanakan secara terintegrasi dan terpadu dalam satu kesatuan komando. Pada prinsipnya pembentukan BAKAMLA adalah menggantikan Badan Koordinasi Keamanan Laut (BAKORKAMLA). Jika pada masih BAKORKAMLA yang merupakan system Multi Agency Single Tasks satu kesatuan komando dengan berbagai macam tugas. BAKAMLA ini diharapkan dapat berfungsi dengan baik dalam penegakan hukum, keamanan dan keselamatan di laut, yang tugasnya terdiri dari aspek-aspek pelyanan system informasi peringatan dini, penegakan hukum di laut, beacukai, keamanan, dan keselamatan pelayaran, pengendalian sumber daya alam hayati dan non-hayati dalam lingkungan kelautan, pencarian dan pertolongan di laut serta pertahanan negara dalam keadaan perang sebagaimana dimaksud dalamPasal 63 UU Kelautan.

Selama ini lembaga yang ada menjalankan fungsi tersebut tidak terintegrasi dalam sebuah lembaga, sehingga belum dapat berjalan dengan optimal. Praktik selama ini menunjukkan bahwa penegakan hukum, keamanan dan keselamatan di laut yang dilaksanakan oleh satuan-satuan patrol dari berbagai Instansi/Kementerian belum mampu menciptakan keamanan laut di perairan Indonesia. Hal ini akan sulit dicapai karena masing-masing instansi mempunyai strategi/kebijakan, peralatan (sarana dan prasarana), SDM yang berbeda-beda, tidak dalam satu sistem yang terintegrasi, serta dalam kesatuan system komando dan kendali. Sehingga dapat dimengerti jika dalam pelaksanaan yang sering terjadi over lapping kewenangan dan friksi antar instansi bahkan ego sektoral diantara instansi atau lembaga tersebut besar kemungkinan terjadi.

22 Ibid, hl. 9 
Dengan menyatukan/mengintegrasikan kewenangan tersebut pada satu badan akan lebih memudahkan untuk melakukan koordinasi dan control disebabkan komando dan kendali ada pada satu tangan (tidak sektoral). BAKAMLA ini dibentuk sebagai wadah pengintegrasian seluruh atau sebagian fungsi atau kewenangan untuk melakukan penegakan hukum, keamanan dan keselamatan di laut yang selama ini masih dilaksanakan secara sektoral berada di stakeholder (kementerian/instansi terkait).

Pada saat ini masih ditemukan adanya interoperabilitas yang belum optimal antara BAKAMLA dengan TNI Angkatan Laut, yaitu:

1) Belum adanya pembaharuan Nota Kesepahaman antara BAKAMLA dengan Mabes TNI yang ditanda tangani oleh masing-masing pejabat yang masih eksis, yang ada adalah Nota Kesepahaman tahun 2015, sedangkan penggunaan kapal perang TNI AL oleh BAKAMLA untuk melaksanakan patrol harus mendapat ijin Mabes TNI (Persetujuan Panglima TNI), hal tersebut mengakibatkan permintaan dukungan kapal perang TNI AL oleh BAKAMLA tidak didukung;

2) BAKAMLA masih terbatas pada Undang-Undang Republik Indonesia Nomor 32 tahun 2014 tentang Kelautan Pasal 63 ayat(2), bahwa kewenangan BAKAMLA adalah memberhentikan, menangkap, memeriksa, dan membawa, serta menyerahkan kapal tangkapan ke instansi lain yang terkait dan berwenang untuk selanjutnya melaksanakan proses hukum lanjutan, hal tersebut menunjukkan bahwa BAKAMLA bukanlah sebagai penyidik di laut sehingga tidak mempunyai kewenangan penyidikan sampai dengan penuntutan;

3) Belum adanya Peraturan Pemerintah atau kebijakan nasional yang mengatur tentang pola operasi keamanan dan keselamatan laut khususnya yang berkaitan dengan tugas, wewenang, dan tanggung jawab instansi sehingga pelaksanaan operasi keamanan di laut menjadi lebih sinergis, optimal dan tidak terjadi tumpang tindih antar instansi di laut.

Sebagai bentuk perwujudan upaya yang serius dalam menanggulangi tindak pidana di laut, pada bulan juli 2020, BAKAMLA resmi membentuk Indonesia Maritime Information Center (IMIC) guna mendukung kewaspadaan maritime (maritime domain awareness) bagi para pengguna laut. Pengamat Militer dan Intelijen Susaningtyas Kertopati menilai, secara internal TNI AL memang perlu mendorong BAKAMLA untuk lebih berperan di zona delimitasi. Sesuai hukum laut internasional memang kapal-kapal BAKAMLA sebagai Indonesia Coast Guard lebih berwenang beroperasi di zone delimitasi sementara kapal-kapal perang TNI AL beroperasi di wilayah perbatasan laut yang sudah disepakati kedua negara. ${ }^{23}$

Namun UU Kelautan tidak menjelaskan secara tegas siapa yang berhak untuk mengintegrasikan dan mengendalikan dalam satu kesatuan komando. Dengan kondisi demikian maka perlu adanya ketegasan dalam bentuk peraturan pemerintah yang

23 Sucipto, Interoperabilitas TNI AL-BAKAMLAKunciSuksesDiplomasiMaritim Indonesia, https://nasional.sindonews.com/read/109800/14/interoperabilitas-tni-al-BAKAMLA-kunci-suksesdiplomasi-maritim-indonesia-1595416031diakses pada 4 Februari 2021 
menegasakan dan menunjuk bahwa BAKAMLA diberi kewenangan untuk mensinergikan dan menjadi komando dalam penagakan hukum di laut.

Berbicara penegakan hukum dan kedaulatan, berdasarkan konsep dan hakikatnya keduanya berbeda. Kata kedaulatan berasal dari bahasa Inggris 'sovereignty' yang berasal dari kata latin 'superanus' berarti yang teratas. Negara dikatakan berdaulat atau sovereign karena kedaulatan merupakan sifat atau cirri hakiki negara. Apabila dikatakan bahwa suatu negara itu berdaulat, dimaksudkan bahwa negara itu mempunyai kekuasaan tertinggi. Walaupun demikian, kekuasaan tertinggi ini mempunyai batas-batasnya. Ruang keberlakuan kekuasaan tertinggi ini dibatasi oleh wilayah negara itu, artinya suatu negara hanya memiliki kekuasaan tertinggi di dalam batas wilayahnya. Jadi, pengertian kedaulatan sebagai kekuasaan tertinggi mengandung dua pembatasan penting dalam dirinya yaitu: ${ }^{24}$

1) Kekuasaan terbatas pada batas wilayah negara yang memiliki kekuasaan itu;

2) Kekuasaan itu berakhir ketika kekuasaan suatu negara lain dimulai.

Dalam konteks hubungan internasional, prinsip kedaulatan negara memiliki kekuasaan atas suatu wilayah (teritorial) serta hak-hak yang kemudian timbul dari penggunaan kekuasaan teritorial. Kedaulatan mengandung arti bahwa negara mempunyai hak kekuasaan penuh untuk melaksanakan hak teritorialnya dalam batas-batas wilayah negara yang bersangkutan. ${ }^{25}$ Dalam Pasal 2 ayat (1) Piagam PBB yang dipertegas lagi dalam Resolusi Majelis Umum Nomor 2625/1970 General Assembly Declaration on Principles of International Law Concerning Friendly Relations and Cooperation Among States in Accordance with the Charter of the United Nations, prinsip kedaulatan merupakan salah satu prinsip dasar yang paling penting dan dihormati terutama di dalam kesamaan posisi hak antar negara di dunia. ${ }^{26} \mathrm{Hal}$ ini merupakan salah satu prinsip atau doktrin yang disebut dengan "jus cogens" atau "peremptory norms", yaitu: "Suatu norma yang diterima sebagai norma dasar hukum internasional dan diakui oleh masyarakat internasional secara keseluruhan sebagai suatu norma yang tidak boleh dilanggar", dapat diartikan bahwa di dalam suatu kedaulatan terdapat suatu wilayah kewenangan/yurisdiksi yang melekat dan tidak dapat terpisahkan dari kedaulatan itu sendiri. Prinsip kedaulatan negara menetapkan bahwa suatu negara memiliki kekuasaan atas suatu wilayah/teritorial serta hak-hak yang kemudian timbul dari penggunaan kekuasaan teritorial. Kedaulatan mengandung arti bahwa negara mempunyai hak kekuasaan penuh untuk melaksanakan hak teritorialnya dalam batas-batas wilayah negara yang bersangkutan. Prinsip kedaulatan negara menegaskan bahwa dilarang melakukan campur tangan terhadap keberadaan negara lain.

Negara-negara anggota PBB merefleksikan persamaan di depan hukum (equality before the law), yaitu:27 "Setiap negara menikmati personalitas hukum yang sama (the same legal h. 16-18.

${ }^{24}$ Mochtar Kusumaatmadja and Etty R Agoes, Pengantar Hukum Internasional (Bandung: Alumni, 2015),

${ }^{25}$ M. Iman Santoso, PerspektifImigrasiDalam United Nation Convention Against Transnational Organized Crima (Cetakan 1), PerumPercetakan Negara RI, Jakarta, 2007, hal. 37

26 M Iman Santoso, "Kedaulatan Dan Yurisdiksi Negara DalamSudut Pandang Keimigrasian," Binamulia Hukum 7, no. 1 (2018): 1-16.

27 Bruno Simma et al., The Charter of the United Nations: A Commentary (Berlin: Oxford University Press, 1995), h. 73-89. 
personality) tanpa membedakan ukuran geografis, jumlah penduduk, kekuatan militer, kekuatan ekonomi, dan sebagainya." "Prinsip kedaulatan mencakup pengertian kedaulatan intern dan extern (internal and external sovereignty). Kedaulatan internal dan eksternal ini saling terkait dan bahkan kedaulatan eksternal merefleksikan konsekuensi logis adanya kedaulatan internal," dengan demikian penegakan kedaulatan adalah penegakan kekuasaan tertinggi dari suatu negara atas suatu wilayah/territorial serta hak-hak yang kemudian timbul dari penggunaan kekuasaan teritorial.

Sedangkan penegakan hukum dapat juga diartikan sebagai penyelenggaraan hukum oleh petugas penegak hukum dan oleh setiap orang yang mempunyai kepentingan sesuai dengan kewenangannya masing-masing menurut aturan hukum yang berlaku. Menurut Soerjono Soekanto, penegakan hukum adalah kegiatan menyerasikan hubungan nilai-nilai yang terjabarkan di dalam kaidah- kaidah/pandangan nilai yang mantap dan sikap tindak sebagai rangkaian penjabaran nilai tahap akhir untuk menciptakan, memelihara dan memepertahankan kedamaian pergaulan hidup. ${ }^{28}$ Satjipto Rahardjo berpendapat bahwa penegakan hukum itu bukan merupakan suatu tindakan yang pasti, yaitu menerapkan hukum terhadap terhadap suatu kejadian, yang dapat di ibaratkan menarik garis lurus antara dua titik. ${ }^{29}$ Penegakan hukum secara konkret ialah berlakunya hukum positif di dalam praktik yang harus ditaati. Jadi, memberikan keadilan di dalam suatu perkara berarti memutuskan hukum $i$ concreto di dalam menjamin dan mempertahankan di taatinya hukum materiil dengan menggunakan cara prosedural yang ditetapkan oleh hukum formal. ${ }^{30}$

Penegakan hukum hakikatnya merupakan upaya menyelaraskan nilai-nilai hukum dengan merefleksikan di dalam bersikap dan bertindak di dalam pergaulan demi terwujudnya keadilan, kepastian hukum dan kemanfaatan dengan menerapkan sanksisanksi. Penegakan hukum dalam bahasa Indonesia dikenal beberapa istilah di luar penegakan hukum tersebut, seperti penerapan hukum, tetapi tampaknya istilah penegakan hukum adalah yang paling sering kali digunakan, dengan demikian, pada waktu-waktu mendatang istilah tersebut akan semakin mapan atau merupakan istilah yang dijadikan (coined), dalam bahasa asing dikenal juga berbagai peristilahan, seperti Rechtstoelpassing/Rechtshandhaving (Belanda), Law Enforcement (Inggris), Application (Amerika). ${ }^{31}$

Penegakan hukum tidak hanya mencakup law enforcement tetapi juga peach maintenance. Menurut Friedman, dalam penegakan hukum pidana dipengaruhi oleh 3 aspek penting, yakni: ${ }^{32}$

${ }^{28}$ Soerjono Soekanto, Faktor-Faktor Yang Mempengaruhi Penegakan Hukum (Jakarta: Jakarta: Raja Grafindo Persada, 1993), h. 35.

${ }^{29}$ Satjipto Rahardjo, Sosiologi Hukum: Perkembangan Metode Dan Pilihan Masalah (Yogyakarta: Genta Publishing, 2010), h. 190.

${ }^{30}$ Dellyana Shant, Konsep Penegakan Hukum (Yogyakarta: Sinar Grafika, 1988), h. 33.

${ }^{31}$ Sidik Sunaryo, Kapita Selekta Sistem Peradilan Pidana (Malang: Universitas Muhammadiyah Malang Press, 2004), h. 3.

32 Erwin Ubwarin, "Penegakan Hukum Yang Dilakukan Oleh Polair Polda Maluku," Jurnal Muara Ilmu Sosial, Humaniora, Dan Seni 2, no. 1 (2018): 44-51. 
1) Legal Structure (struktur hukum), dapat diartikan sebagai institusi yang menjalankan penegakan hukum dengan segala proses yang berlangsung di dalamnya. Institusi ini dalam sistem yang terdiri atas kepolisian, kejaksaan, pengadilan dan lembaga pemasyarakatan yang menjamin berjalannya proses peradilan pidana;

2) Legal Substance (substansi hukum), adalah aturan, norma dan pola perilaku nyata manusia yang berada di dalam system tersebut;

3) Legal Culture (budaya hukum), sebagai sikap masyarakat terhadap hukum dan system hukum itu sendiri. Sikap masyarakat ini mencakup kepercayaan, nilainilai dan ide-ide, serta harapan mereka tentang hukum dan system hukum. Hal ini karena pada hakikatnya penegakan hukum merupakan proses penyesuaian antara nilai-nilai, kaidah-kaidah dan pola perilaku nyata yang bertujuan untuk mencapai kedamaian. Oleh karena itu tugas utama penegakan hukum adalah mencapai keadilan.

Letak Indonesia yang berada di antara dua benua dan Asia dan Australia serta Samudera Indonesia dan Samudera Pasifik dan merupakan negara kepulauan yang terbesar di dunia yang terdiri dari kurang lebih 17.590 pulau memiliki luas 18 juta kilo meter persegi. Perairan Indonesia terdapat sekurang-kurangnya tujuh buah selat penting bagi pelayaran internasional. Ketujuh buah selat itu adalah Selat Malaka, Selat Singapura, Selat Sunda, Selat Lombok, Selat Makassar, Selat Wetar dan Selat Makassar. ${ }^{33}$

Pada pasca kemerdekaan untuk mencegah agar lautan Indonesia tidak digunakan kapal-kapal asing yang dapat mengancam keutuhan negara, Pemerintah Indonesia kemudian mengambil langkah mengintegrasikan wilayah Republik Indonesia sebagai suatu wilayah yang utuh menyeluruh dengan mengumumkan berlakunya Asas Negara Kepulauan (archipelago state principles) pada tanggal 13 Desember 1957 yang dikenal dengan Deklarasi Juanda menyatakan: ${ }^{34}$

“Segala perairan di sekitar di antara dan yang menghubungkan pulau-pulau atau bagian pulau-pulau termasuk daratan negara Indonesia, dengan tidak memandang lebar atau luasnya adalah bagian dari wilayah Indonesia. Penentuan batas laut territorial dari garis yang menghubungkan titik-titik ujung terluar pada pulau-pulau negara Indonesia sejauh 12 mil."

Dalam perairan Indonesia yang sangat luas tersebut, terdapat juga laut Maluku yang terletak di barat Samudera Pasifik yang terletak di dekat Provinsi Maluku, Indonesia. Laut Maluku membatasi Laut Sulawesi di utara dan Laut Banda di selatan. Pulau-pulau yang membatasi laut ini adalah kepulauan Indonesia seperti Halmahera, Seram, Buru, dan Sulawesi (Celebes). ${ }^{35}$

Provinsi Maluku sebagai provinsi kepulauan, secara geografis memiliki luas $712.479,69 \mathrm{Km}^{2}$, dengan luas lautan sebesar $658.294,69 \mathrm{Km}^{2}$ atau $(92,4 \%)$ dan luas daratan

33 Romli Atmasasmita, Tindak Pidana Narkotika Transnasional Dalam Sistem Hukum Pidana Indonesia (Bandung: Citra Aditya Bakti, 1997), h. 2.

${ }^{34}$ Eddy Damian, Kapita Selekta Hukum Internasional (Bandung: Alumni, 1991), h. 21.

35https://id.wikipedia.org/wiki/Laut_Malukudiakses pada 18 Januari 2021 
$54.185 \mathrm{Km}^{2}$ atau (7,6\%). Luas daratan terdiri dari pulau-pulau besar dan kepulauan kecil, baik secara berkelompok maupun terpencil. Dengan luas lautan yang (92,4\%) tersebut, tersimpan potensi kekayaan alam berupa ikan, yang umumnya terdapat di sekitar Laut Seram, Laut Banda dan Laut Arafura, sehingga hasilnya dapat dimanfaatkan secara nasional sebesar $(26,3 \%)$ per tahunnya, di mana tergambar bahwa potensi perikanan nasional sebesar 6,26 juta ton/tahun, sedangkan potensi perikanan Provinsi Maluku adalah sebesar 1,64 juta ton/tahun atau (26,3\%) dari potensinasional.

Luas wilayah perairan tersebut senantiasa harus selalu dijaga dan diawasi setiap saat dari orang maupun badan Hukum yang melakukan kegiatan di perairan. TNI AL dan BAKAMLA merupakan Aparat Penegak Hukum yang bertanggung jawab sebagaimana di amanatkan dalam Undang- undang untuk melaksanakan tugas tersebut, karena memiliki fasilitas kapal sebagai sarana utama untuk melaksanakan patroli di wilayah perairan. Adapun perairan yang dimaksud adalah perairan pedalaman, perairan kepulauan, laut teritorial, zona tambahan sampai dengan zona ekonomi ekslusif Indonesia, sebagaimana diatur dalam UNCLOS tahun 1982 yang diratifikasi oleh Undang-Undang Nomor17 tahun 1985 tentang Pengesahan United Nations Conventions On The Law Of The Sea (selanjutnya disingkat UU Pengesahan UNCLOS).

Tugas TNI AL dan BAKAMLA yang penegakan hukum dan penegakan kedaulatan di laut harus berpedoman kepada wilayah negara Republik Indonesia sesuai ketentuan yang diatur dalam Undang-Undang Nomor 43 Tahun 2008 tentang Wilayah Negara (selanjutnya disingkat UU Wilayah Negara) khsusunya pada Bab III dan memperhatikan perkembangan batas wilayah negara yang telah ditetapkan atas dasar perjanjian bilateral dan/atau trilateral, sehingga operasional TNI AL dan BAKAMLA tidak sampai keluar batas wilayah laut yang menjadi kewenangan atau melanggar hukum internasional.

Pelaksanaan peran penegakan hukum dan penegakan kedaulatan TNI AL dan BAKAMLA diimplementasikan dalam sebuah pedoman bagi unsur operasional dan pangkalan dalam menangani setiap tindak pidana di laut. TNI AL juga telah memilik Peraturan Kasal Nomor 32/V/2009 tanggal 4 Mei 2009 tentang Prosedur Tetap Penegakan Hukum dan Penjagaan Keamanan di Wilayah Laut Yurisdiksi Nasional oleh TNI AL. Peraturan Kasal tersebut bertujuan untuk memberikan keseragaman dan kepastian hukum bagi penyidik TNI AL dalam menangani tindak pidana di laut secara profesional dan proporsional sesuai dengan ketentuan Hukum Laut Internasional dan Hukum Nasional.

Selain itu ditinjau dengan menggunakan teori, menurut Philipus $M$ Hadjon mengemukakan bahwa kewenangan diperoleh melalui tiga sumber yaitu atribusi, delegasi, mandat. Kewenangan atribusi lazimnya digariskan melalui pembagian kekuasaan negara oleh Undang-Undang, kewenangan delegasi dan mandat adalah kewenangan yang berasal dari pelimpahan. Setiap kewenangan dibatasi oleh isi atau materi wilayah dan waktu. Pada kewenangan delegasi, harus ditegaskan suatu pelimpahan wewenang kepada organ pemerintahan yang lain. Pada mandat tidak terjadi pelimpahan apapun dalam arti pemberian wewenang, akan tetapi, yang diberi mandat bertindak atas nama pemberi mandat. Dalam pemberian mandat, pejabat yang diberi mandat menunjuk pejabat lain untuk bertindak atas nama mandator (pemberi mandat). 
Di lain itu, Indro harto menyebutkan bahwa kewenangan yang bersifat terikat terjadi apabila peraturan dasarnya menentukan kapan dan dalam keadaan yang bagaimana kewenangan tersebut dapat digunakan atau peraturan dasarnya sedikit banyak menentukan tentang isi dan keputusan yang harus diambil.

Dari beberapa uraian di atas, maka dapat diketahui bahwa kewenangan LANTAMAL IX dan BAKAMLA Zona Maritim Timur merupakan kewenangan atributif, yaitu kewenangan yang diberikan langsung oleh peraturan perundang-undangan. Oleh karena itu dalam penegakan kedaulatan dan penegakan hukum di perairan Maluku, baik BAKAMLA Zona Maritim Timur dan LANTAMAL IX sesuai dengan kewenangannya dapat bekerjasama dengan untuk melakukan tindakan-tindakan terhadap setiap pelaku tindak pidana di laut berdasarkan ketentuan UU Wilayah Negara, UU Kelautan, UU Perairan, UU TNI, Peraturan Presiden Nomor 178 Tahun 2014 tentang Badan Keamanan Laut dan Peraturan Kasal Nomor 32/V/2009 tertanggal 4 Mei 2009 untuk tujuan memberikan keseragaman dan kepastian hukum dalam menangani tindak pidana di laut secara profesional dan proporsional dengan ketentuan hukum laut internasional dan hukum nasional.

\subsection{Hambatan Yang Dihadapi LANTAMAL IX dan KAMLA ZONA MARITIM TIMUR Dalam Penegakan Hukum di Laut Maluku}

Adapun hambatan atau faktor-faktor yang mempengaruhi penegakan hukum terhadap tindak pidana di laut antara BAKAMLA dengan TNI AL, adalah:

1) BAKAMLA sampai dengan saat ini hanya memiliki 6 (enam) kapal, kapal-kapal tersebut berukuran 48 Meter, sedangkan BAKAMLA memiliki anggaran yang cukup besar untuk pelaksanaan operasi. Maka dalam hal ini melalui Operasi Terpadu, BAKAMLA menyediakan anggaran operasi bagi unsur Stakeholder yang tergabung di dalam Operasi Terpadu tersebut dan tidak hanya pada operasi, BAKAMLA juga mendukung kebutuhan anggaran yang timbul dari proses hukum terhadap hasil tangkapan pada Operasi Terpadu.

2) Sinergitas operasi maupun sharing data dan informasi yang sudah terjalin antara BAKAMLA dengan TNI AL dapat membangun keamanan dan keselamatan, baik di wilayah perairan maupun wilayah yurisdiksi Indonesia. Hal ini harus di dukung oleh koordinasi dan komunikasi yang baik dari kedua instansi.

3) Belum efektifnya pengamanan laut Indonesia, hal ini dikarenakan masih terbatasnya unsur yang diperbantukan ke dalam Operasi Terpadu yang diselenggarakan oleh BAKAMLA, sehingga masih dalamPasal 61 UU Kelautan.

4) Hasil sangat terkait dengan efektifitas, hasil tidak akan maksimal jika pelaksanaan tersebut tidak efektif. Seperti pada halnya Operasi Terpadu oleh BAKAMLA, karena belum efektifnya pelaksanaan operasi maka berdampak pada belum maksimalnya dalam penanggulangan tindak pidana di laut Indonesia.

5) Belum adanya kebijakan nasional yang mengatur secara jelas tentang tugas dan wewenang tiap instansi di bidang keamanan laut, masih adanya ego sektoral antar instansi di laut, serta belum jelasnya secara hukum BAKAMLA ketika melakukan penangkapan kapal apakah melakukan penyidikan atau penyelidikan, BAKAMLA tidak memiliki kewenangan penyidikan sehingga proses penyidikan 
dilakukan instansi yang berwenang, belum adanya prosedur terkait pola, sektor dan kebutuhan operasi keamanan laut dan perlunya sharing information, masih terbatasnya sarana dan prasarana BAKAMLA seperti; kapal patroli, pangkalan, dukungan logistic BBM dan masih terbatasnya peralatan komunikasi.

Hal-hal yang telah diungkapkan di atas, juga menjadi kendala dalam melakukan penegakan hukum di perairan Maluku antaraLantamal IX dan BAKAMLA Zona Maritim Timur. Sehingga perlunya dilakukan pengkajian secara mendalam agar mendapatkan hasil efektif dan adanya aspek interoperabilitas serta sinergitas dalam penegakan hukum di perairan Maluku antara Lantamal IX dan BAKAMLA Zona Maritim Timur.

Selanjutnya, dengan adanya beberapa permasalahan tersebut, perlu dilakukan harmonisasi hukum sebagai upaya dalam meningkatkan aspek interoperabilitas dan sinergitas antara Lantamal IX dan BAKAMLA Zona Maritim Timur. Adapun beberapa faktor yang menjadi hambatan dalam harmonisasi kewenangan penegakan hukum dalam menanggulangi tindak pidana di laut, yaitu:

\section{a. Faktor Dominasi Ego Sektoral Penegakan Tindak Pidana di Laut}

Sejak awal pembentukan undang-undang perikanan, kewenangan penyidikan terhadap tindak pidana di bidang perikanan merupakan salah satu persoalan yang timbul dalam pembahasan Rancangan Undang-Undang (RUU) Perikanan (sekarang menjadi Undang-Undang RI Nomor 45 Tahun 2009 tentang Perubahan atas Undang- Undang Nomor 31 Tahun 2004 tentang Perikanan). TNI AL ingin dilibatkan dalam penyidikan terhadap kasus pelanggaran laut di luar Zona Ekonomi Ekslusif (ZEE) Indonesia, permintaan tersebut terkait fungsi, tugas dan wewenang untuk mengawasi serta menangkap pelanggaran di semua wilayah perairan. Permasalahan menjadi lebih kompleks karena POLRI juga ingin dilibatkan sebagai penyidik dalam penegakan hukum terhadap tindak pidana di bidang perikanan. POLRI beralasan bahwa Polisi eksis sebagai alat negara yang berperan dalam memelihara keamanan dan ketertiban masyarakat, menegakkan hukum, memberikan pengayoman dan pelayanan kepada masyarakat. Dengan demikian, POLRI juga mempunyai wewenang sebagai penyidik terhadap tindak pidana di bidang perikanan

Pemberian kewenangan yang sama dalam hal penyidikan terhadap tindak pidana di bidang perikanan merupakan hasil kompromi politis diantara tiga instansi penyidik. Namun demikian, kompromi politis tersebut sangatlah tepat mengingat tidak mungkin untuk menyerahkan kewenangan penyidikan hanya kepada satu instansi penyidik sebagai penyidik tunggal, dengan alasan: Penyelenggaraan SPDP dapat dipahami sebagai mekanisme bekerjanya aparat penegak hukum pidana mulai dari proses penyidikan, penuntutan, pemeriksaan di siding pengadilan serta pelaksanaan keputusan pengadilan. Keempat komponen ini bekerja sama membentuk apa yang dikenal dengan "integrated criminal justice system administration" dan mempunyai hubungan yang bersifat interdependen, yakni pendekatan system peradilan terhadap peradilan pidana yang membuka ruang adanya konsultasi dan kooperasi antara sub-sistem. Sinkronisasi substansial (substansial synchronization) mencakup singkronisasi peraturan perundangundangan yang berkaitan tugas dan wewenang aparat penegak hukum dan hakim. Sebagai contoh singkronisasi Undang - UndangNomor 8 Tahun 1981 tentang Kitab Hukum Acara 
Pidana (KUHAP) dengan peraturan lainnya, sehingga diharapkan dapat memberikan acauan yang jelas bagi para penegak hukum. Sinkronisasi struktural (cultural sychronization) dalam melaksanakan tugas dan wewenang mencakup keselarasan dalam mekanisme penyelenggaraan peradilan pidana dalam kerangka hubungan antar sub-sistem. Selain kepolisian, penyidikan dilakukan juga oleh penyidik PPNS atau penyidik lainnya.

Untuk menjembatani "egosektoral" penyidik, peneliti berpendapat seharusnya Departemen Kelautan dan Perikanan sebagai Departemen yang bertangung jawab dalam pengelolaan Kelautan dan Perikanan Indonesia dapat mensosialisasikan kembali UndangUndang Nomor 45 Tahun 2009 tentang perubahan atas Undang-UndangNomor 31 Tahun 2004 dan semangat yang melatar belakangi pembentukannya kepada masing masing instansi penyidik sehingga "egosektoral" masing-masing penyidik dapat dihilangkan. Pemberian kewenangan penyidikan dalam penyidikan tindak pidana di bidang perikanan kepada perwira TNI AL, PPNS Perikanan, dan pejabat polisi Negara Republik Indonesia yang mengandung konsekuensi bahwa masing-masing instansi penyidik berhak untuk melakukan penyidikan tindak pidana di bidang perikanan yang terjadi di seluruh wilayah perairan Indonesia, dan Zona Ekonomi Ekslusif Indonesia. Konsekuensi ini menimbulkan kekhawatiran adanya tumpang tindih penyidikan terhadap tindak pidana di bidang perikanan.

Dalam praktek di lapangan, untuk menghindari hal tersebut, maka penyidikan tindak pidana di laut di dasarkan pada kesepakatan tidak tertulis antar penyidik, yaitu bahwa siapa yang mengetahui atau patut menduga telah terjadi suatu tindak pidana maka dia lah yang berhak untuk melakukan penyidikan. Kesepakatan tidak tertulis ini bukan tanpa konsekuensi karena bias saja terjadi di satu spot yang samater dapat tiga kapal penyidik dari instansi yang berbeda dan ini berarti ketidak efesienan dan berakibat tidak optimalnya penegakan hukum.

\section{b. Faktor Ancaman Keamanan dari Pelaku Tindak Pidana Laut}

Sebagai negara kepulauan yang sering disebut zamrud khatulistiwa, maka Indonesia, terkhusus Maluku, memiliki konfigurasi untuk sekaligus amat menantang bagi negara lain untuk turut menikmati sumber daya alamnya. Kondisi seperti itu menempatkan Indonesia pada kedudukan dan peranan penting dalam hubungan dengan dunia internasional sebagai centre of gravity dikawasan Asia-Pasifik. Posisi Indonesia yang terletak di antara dua benua dan dua samudera juga tidak luput dari kerawanan yang tinggi terhadap ancaman serta pengaruh dari luar. Posisi geografis tersebut banyak dimanfaatkan oleh pihak luar yang melakukan kegiatan-kegiatan terlarang maupun tanpa ijin di wilayah perairan Indonesia (termasuk Maluku) khususnya berkaitan dengan sumber daya alam. Ancaman pelanggaran hukum (law transgression threat) yaitu tidak patuhinya hukum nasional maupun internasional yang berlaku di perairan yurisdiksi nasional termasuk illegal fishing.

Untuk mengatasi tindak pidana tertentu di laut seperti ini sebenarnya sudah ada badan yang menanganinya yaitu BAKAMLA. Akan tetapi permasalahan di bidang perikanan sebagaimana diatur UU Perikanan lembaga yang berwenang dalam penegakan hukum sebagai penyidik adalah PPNS, Polri dan TNI AL sebagaimana diatur pada Pasal 73 sebagai berikut: 
(1) Penyidik tindak pidana di bidang perikanan di wilayah pengelolaan perikanan di Negara Republik Indonesia dilakukan oleh Penyidik Pegawai Negeri Sipil Perikanan, Penyidik Perwira TNI AL, dan/atau Penyidik Kepolisian Republik Indonesia.

(2) Selain penyidik TNI AL, Penyidik Pegawai Negeri Sipil Perikanan berwenang melakukan penyidikan terhadap tindak pidana di bidang perikanan yang terjadi di ZEEI.

(3) Penyidikan terhadap tindak pidana di bidang perikanan yang terjadi di pelabuhan perikanan, diutamakan dilakukan oleh Penyidik Pegawai Negeri Sipil Perikanan.

(4) Penyidik sebagaimana dimaksud pada ayat (1) dapat melakukan koordinasi dalam penanganan penyidikan tindak pidana di bidang perikanan.

(5) Untuk melakukan koordinasi dalam penanganan tindak pidana di bidang perikanan sebagaimana dimaksud pada ayat (4), Menteri membentuk forum koordinasi.

\section{c. Faktor Regulasi dan Peraturan Perundang-undangan Mulai Dari Proses Pembuatan, Pelaksanaan, dan Pengawasannya}

Kebijakan di bidang pengawasan dan pengendalian terhadap tindak pidana di laut dipandang belum efektif. Para pelaku tindak pidana di laut sadar betul bahwa pengawasan hukum di Indonesia masih sangat lemah. Ditunjang dengan struktur negara kepulauan yang membuat para penegak hukum memiliki banyak kendala dalam melakukan pengawasan. Selama ini berbagai peraturan dan kebijakan yang terkait dengan tindak pidana laut melekat pada berbagai sektor, sehingga pengawasan maupun penanganannya dilakukan sangat sektoral pula. Disamping aparat penegak hukum seperti PPNS, Polri dan aparat penjaga teritorial seperti TNI AL, untuk mengawasi periknanan dengan wilayah yang sangat luas belum diimbangi dengan kemampuan kapal dan pesawat udara patroli maritim, fasilitas dan SDM.

\section{d. Faktor Kompetensi Sumber Daya Manusia (SDM) Penegak Hukum Tindak Pidana Laut Tidak Optimal}

Realita tindak pidana di laut jelas didasari untuk mengeruk keuntungan pribadi/korporasi semata dengan mengesampingkan kepentingan umum. Adanya oknum pejabat yang dapat di suap dalam pengurusan perizinan sehingga dapat mengakibatkan meningkatnya jumlah orang atau korporasi yang ingin ikut melakukan hal tersebut bahkan ada juga para pejabat yang bukan hanya membantu masalah perizinan namun malah melindungi tindakan kejahatan yang di lakukan oleh para pelaku tersebut. Perbuatan tersebut sering di lakukan oleh oknum dari instansi- instansi terkait yang bertujuan untuk mencari keuntungan pribadi.

Dari fakta yang ada maka sangatlah penting untuk meningkatkan kemampuan sumber daya aparat penegak hukum perlu ditingkatkan melalui pelatihan secara formal tidak hanya pada materi hukum tindak pidana laut semata tetapi juga berkaitan dengan hukum acara yang khusus diatur dalam peraturan perundang-undangan di Indonesia. Selanjutnya untuk memenuhi ketentuan penegakan menurut etika dan moral, maka SDM penegak hukum harus disumpah menurut kewenangan yang berlaku sebagai penyidik tindak pidana di laut yang sah. 


\section{e. Faktor Sarana dan Prasarana}

Infra struktur pengamanan pasar domestik terutama pada pelabuhan perikanan dan kapal/pesawat udara sebagai Alut sista di perairan laut perlu ditingkatkan. Minimnya infrastruktur pengamanan tersebut, tidak sebanding dengan luas wilayah laut yang harus diamankan dari tindak pidana di laut. Rasio antara armada kapal yang dimiliki oleh PPNS Perikanan, Polisi Perairan, dan TNI AL tidak sebanding dengan luas wilayah dan jumlah pelabuhan. Tidak dipungkiri jika daerah-daerah rawan tindak pidana laut termasuk di Laut Arafuru dan Natuna tidak mampu lagi ditangani oleh personel penegak hukum tindak pidana laut yang ada. Pada era sekarang ini kemampuan kapal perikanan asing jauh lebih tangguh, sehingga otoritas kepabeanan dan keamanan semakin terkendala dalam mengawasi pelabuhan dan kawasan yang rawan.

Faktor sarana yang dibutuhkan oleh instansi penegak hukum perikanan tidak hanya dalam bentuk kapal-kapal patroli yang memiliki kemampuan berlayar di seluruh perairan wilayah Indonesia tetapi juga dilengkapi dengan kemampuan kesenjataan yang ditujukan untuk melumpuhkan kapal-kapal perikanan yang tidak mentaati perintah atau yang melakukan unlawfull act. Selain sarana kapal yang dilengkapi dengan senjata juga diperlukan navigasi dan sistem informasi kendali yang terintegrasi dengan pusat komando. Sarana yang tidak kalah penting sarana yang dibutuhkan adalah pesawat udara yang memiliki kemampuan bermanuvra di atas permukaan air laut dengan baik misalnya dengan pesawat baling-baling kelas medium atau pesawat amfibi.

Selanjutnya berbicara harmonisasi penegakan hukum sebagai upaya dalam menaggulangi tindak pidana laut di perairan Maluku, berlakunya Undang-UndangNomor 17 Tahun 2008 tentang Pelayaran (selanjutnya disingkat UU Pelayaran) yang difokuskan pada jenis alat transportasi yang digunakan melalui jalur perairan sebagaimana diatur dalam Pasal 1 undang-undang ini terdiri dari: angkutan di laut, angkutan sungai, danau serta aktivitas penyeberangan. Hal ini diperjelas dalam Pasal 6 UU Pelayaran. Meskipun demikian bahwa adanya tindak pidana dalam ketentuan tersebut diberlakukan hanya untuk tindak pidana terkait dengan perniagaan dan perijinan serta kegiata npengangkutan.

Wewenang TNI AL dalam hal ini LANTAMAL IX penegakan hukum di wilayah perairan laut Maluku mempunyai 3 (tiga) peranan penting yaitu peran pada bidang militer, peran dalam bidang polisionil dan peran dalam bidang diplomasi. Peran militer, peran polisionil, dan peran diplomasi merupakan peran yang sifatnya universal yang dimiliki oleh TNI AL. Dalam implementasinya, bahwa ketiga peran yang secara yuridis telah diatur dalam UU TNI tentang Tugas TNI Angkatan Laut. Salah satu bentuk tugas yang harus dijalankan TNI AL telah dituangkan dalam Pasal 9 UU TNI. 'Sedangkan tugas penegakan hukum serta sebagai penjaga keamanan secara jelas diatur dalamPasal 1 angka 22 UU TNI. Kemudian penegakan hukum yang dilakukan oleh TNI AL juga secara jelas telah dijelaskan dalam Penjelasan pasal Pasal 9 huruf b UU TNI.

Terkait dengan dasar kewenangan TNI AL dalam menjalankan tugasnya yaitu menegakkan hukum di laut dan diseluruh wilayah perairan Indonesia telah diatur dengan jelas dalam Pasal 9 huruf b UU TNI. Di samping itu bahwa dasar kewenangan TNI AL di dalam melaksanakan tugas memberantas terjadinya tindak pidana yang terjadi di ZEEI 
telah dinyatakan dengan jelas dan tegas pada peraturan dan perundangan lain yang mengatur tentang ZEEI serta secara khusus yang mengatur tentang terjadinya tindak pidana tertentu yang terjadi di wilayah perairan Indonesia.

Ketentuan yang mengatur tentang kewenangan yang diberikan kepada Perwira TNI untuk melaksanakan tindakan penyidikan terhadap tindak pidana yang terjadi di wilayah laut ZEEI telah diatur dalam Pasal 14 Undang-Undang Nomor 5 Tahun 1983 tentang Zona Ekonomi Ekslusif Indonesia (selanjutnya disingkat UU ZEEI). Ketentuan-ketentuan tentang kewenangan TNI AL dalam melaksanakan tugas penyidikan terhadap tindak pidana di wilayah perairan Indonesia semakin kuat dengan diterbitkannya UU Perairan, serta hasil konvensi internasional di antaranya adalah UNCLOS 1982. Di dalam Pasal 24 UU Perairan telah disebutkan dengan tegas tentang proses penegakan hukum atas tindak pidana di wilayah perairan Indonesia. Di dalam Konvensi PBB tentang Hukum Laut (UNCLOS 1982) yang kemudian ditindak lanjuti oleh pemerintah Indonesia dengan melakukan retifikasi dengan Undang-Undang Nomor 17 Tahun 1985. Kewenangan TNI AL yang terdapat dalam UNCLOS 1982 terdapat dalam Pasal 111 ayat (5). Sesuai dengan ketentuan dalam Pasal 111 ayat (5) UNCLOS 1982, bahwa TNI AL mempunyai kewenangan untuk melakukan penegakan atas keutuhan kedaulatan negara juga memiliki kewenangan dalam menegakkan hukum yang sesuai dengan yuridiksi negara atas wilayah perairan lautnya.

Menegakkan hukum di laut harus ada kebijakan operasional yang lebih besar dan sebagai bagian dari pelaksanaan penegakan hukum terhadap tindak pidana laut dilaksanakan secara terintegrasi perlu satu lembaga yang melaksanakan fungsi keamanan di wilayah laut Indonesia, yaitu BAKAMLA, terkhusus untuk laut Maluku terdapat BAKAMLA Zona Maritim Timur.

Penegakan terhadap pelanggaran hukum di laut tidak dapat dipisahkan dari keamanan laut pada umumnya. Terminologi keamanan laut di dalam nya sudah terkandung di dalamnya penegakan hukum perikanan. Oleh karena itu kewenangan secara atributif kepada intitusi TNI AL menjadi centre of grafity pelaksanaan penegakan hukum tindak pidana tertentu di laut di bidang perikanan. Untuk menjaga keutuhan wilayah NKRI (Negara Kesatuan Republik Indonesia) merupakan kewajiban segenap komponen bangsa dengan cara meningkatkan keamanan dan stabilitas negara di segala bidang. Untuk mewujudkan hal tersebut, maka TNI (Tentara Nasional Indonesia) sebagai komponen utama pertahanan mata laut harus berada di garis depan untuk mengamankan dan mempertahankan seluruh wilayah Negara Kesatuan Republik Indonesia termasuk di dalamnya menegakkan hukum kepada pelaku tindak pidana di laut.

TNI AL dan BAKAMLA sebagai komponen utama dalam melaksanakan penegakan wilayah dan hukum di laut melaksanakan perananan diplomasi, polisionil dan pertahanan. Sebagai komponen utama pertahanan di laut, TNI AL wajib untuk menjaga integritas wilayah NKRI dan mempertahankan stabilitas keamanan di laut serta melindungi sumber daya alam di laut dari gangguan keamanan dan pelanggaran hukum di wilayah yuridiksi nasional Indonesia, baik dari dalam maupun luar negeri seperti; illegal logging, trafficking, illegal mainning, illegal entry dan lain sebagainya. Dalam menjalankan tugas menjaga keamanan di laut, TNI AL \& BAKAMLA akan sangat bergantung pada kesiapan armada kapal-kapal perang yang dimiliki. 
Selain harus mengharmonisasi kewenangan antara TNI AL dan BAKAMLA, maka perlu juga untuk melakukan upaya harmonisasi peraturan perundang-undangan juga membuka kemungkinan masyarakat atau pihak-pihak kepentingan untuk melakukan pengujian dengan cara mengajukan permohonan atau gugatan. Permasalahan lain yang menjadi pekerjaan rumah bagi bangsa Indonesia dalam upaya penegakan hukum di laut adalah tumpang tindih tugas pokok dan fungsi masing-masing aparat penegak hukum di laut. Hal ini dapat dilihat dari banyaknya peraturan perundang-undangan yang memberikan kewenangan kepada pihak penegak hukum yang berbeda-beda dalamm enjalankan penegakan hukum di wilayah laut Indonesia, antara lain Undang- Undang tentang Kepabeanan, Undang-Undang tentang Perikanan, Undang-Undang tentang TNI dan Undang-Undang tentang POLRI. Disharmonisasi ini menimbulkan masalah tersendiri, terutama terkait dengan sejauh mana masing-masing penegak hukum menjalankan tugas dan tanggung jawabnya.

Terkait dengan adanya tumpang tindih pengaturan hukum dan kelembagaan di laut, Dewan Keamanan Laut (DKI) pada tahun 2009 melakukan pengkajian terhadap hal tersebut sebagai berikut: ${ }^{36}$

a) Melakukan sinkronisasi dan harmonisasi peraturan perundang-undangan yang berlaku yang selama ini tumpang tindih;

b) Mengkompilasi terhadap peraturan perundang-undangan yang telah ada. Semua peraturan perundang-undangan di laut dihimpun agar lebih memudahkan dalam acuan penegakan hukum di laut;

c) membuat database peraturan perundang-undangan yang berlaku.

Dari uraian di atas tampak bahwa secara filosofis, historis, sosiologis dan yuridis diperlukan penataan hukum kelautan dalam suatu sistem hukum nasional dengan memperhatikan hukum dan peraturan perundang-undangan yang telah ada dan hukum internasional yang berlaku. Berdasarkan fakta yuridis terhadap lemahnya koordinasi dan keterpaduan (integrated) antar para penegak hukum di laut saat ini, muncul suatu gagasan untuk menyerahkan pelaksanaan penegakan hukum tersebut pada suatu lembaga sebagai satu kesatuan komando. Satu komando artinya tidak sekedar koordinatif tetapi ada satu perintah dan pemegang keputusan yang menaungi masing-masing aparat penegak hukum yang telah ada. Hal ini mengingat bahwa penegakan hukum di laut mempunyai ciri-ciri yang khusus dan ruang lingkup yang khusus pula sesuai dengan rezim-rezim hukum yang berlaku di wilayah laut yang bersangkutan.

\section{Kesimpulan}

Interoperabilitas antaraLantamal IX dan Kamla Zona Maritim Timur sebenarnya sudah ada, namun interoperabilitas belum berjalan optimal antara BAKAMLA dengan TNI Angkatan Laut di karenakan belum adanya pembaharuan Nota Kesepahaman antara BAKAMLA dengan Mabes TNI; BAKAMLA masih terbatas pada Kelautan Pasal 63 ayat (2) UU Kelautan; Belum adanya Peraturan Pemerintah atau kebijakan nasional yang mengatur tentang pola operasi keamanan dan keselamatan laut khususnya yang berkaitan dengan

${ }^{36}$ Ranu Samiaji, "Harmonisasi Kewenangan Lembaga Negara Dalam Menanggulangi Tindak Pidana Illegal Fishing Di Perairan Indonesia," Jurnal Hukum, 2015, 1-22. 
tugas, wewenang, dan tanggung jawab instansi. Hambatan atau faktor-faktor yang mempengaruhi penegakan hukum terhadap tindak pidana di laut antara BAKAMLA dengan TNI AL, adalah: BAKAMLA sampai dengan saat ini hanya memiliki 6 (enam) kapal; sinergitas operasi maupun sharing data dan informasi yang sudah terjalin antara BAKAMLA dengan TNI AL dapat membangun keamanan dan keselamatan; baik di wilayah perairan maupun wilayah yurisdiksi Indonesia, belum efektifnya pengamanan laut Indonesia; hasil sangat terkait dengan efektifitas, hasil tidak akan maksimal jika pelaksanaan tersebut tidak efektif; belum adanya kebijakan nasional yang mengatur secara jelas tentang tugas dan wewenang tiap instansi di bidang keamanan laut, masih adanya ego sektoral antar instansi di laut, serta belum jelasnya secara hukum BAKAMLA ketika melakukan penangkapan kapal apakah melakukan penyidikan atau penyelidikan.

\section{Referensi}

Anwar, Syaiful. "Membangun Keamanan Maritim Indonesia Dalam Analisa Kepentingan, Ancaman, Dan Kekuatan Laut." Jurnal Pertahanan E Bela Negara 6, no. 3 (2018): 69-90.

Atmasasmita, Romli. Tindak Pidana Narkotika Transnasional Dalam Sistem Hukum Pidana Indonesia. Bandung: Citra Aditya Bakti, 1997.

Damian, Eddy. Kapita Selekta Hukum Internasional. Bandung: Alumni, 1991.

Hadju, Zainal Abdul Aziz. “Analisis UNCLOS 1982 Terkait Permasalahan Yurisdiksi Negara Dan Penegakan Hukum Atas Kapal Berbendera Negara Asing." SASI 27, no. 1 (2021): 12-23. https:/ / doi.org/10.47268/ sasi.v27i1.254.

Hananto, Akhyari. “Dikukuhkan Di New York Agustus Ini, Inilah Jumlah Resmi Pulau Di Indonesia." $\quad$ www.goodnewsfromindonesia.id, 2017. https:/ / www.goodnewsfromindonesia.id/2017/08/19/dikukuhkan-di-new-york agustus-ini-inilah-jumlah-resmi-pulau-di-indonesia.

Ibrahim, Johnny. Teori Dan Metode Penelitian Hukum Normatif. Malang: Malang: Bayu Media Publishing, 2006.

Kusumaatmadja, Mochtar, and Etty R Agoes. Pengantar Hukum Internasional. Bandung: Alumni, 2015.

Marzuki, Peter Mahmud. Penelitian Hukum,. Jakarta: Kencana, 2016. https://doi.org/340.072.

Rahardjo, Satjipto. Sosiologi Hukum: Perkembangan Metode Dan Pilihan Masalah. Yogyakarta: Genta Publishing, 2010.

Ramdhan, Muhammad, and Taslim Arifin. "Aplikasi Sistem Informasi Geografis Dalam Penilaian Proporsi Luas Laut Indonesia." Jurnal Ilmiah Geomatik 19, no. 2 (2013): 14146.

Rumata, Jamaludin. “Kepulauan Maluku Dalam Geopolitik Regional.” kompastimur.com, 2018. https:/ / www.kompastimur.com/2018/10/kepulauan-maluku-dalamgeopolitik.html.

Samiaji, Ranu. “Harmonisasi Kewenangan Lembaga Negara Dalam Menanggulangi Tindak 
Pidana Illegal Fishing Di Perairan Indonesia." Jurnal Hukum, 2015, 1-22.

Santoso, M Iman. "Kedaulatan Dan Yurisdiksi Negara DalamSudut Pandang Keimigrasian." Binamulia Hukum 7, no. 1 (2018): 1-16.

Shant, Dellyana. Konsep Penegakan Hukum. Yogyakarta: Sinar Grafika, 1988.

Simma, Bruno, Daniel Erasmus Khan, Georg Nolte, and Andreas Paulus. The Charter of the United Nations: A Commentary. Berlin: Oxford University Press, 1995.

Soekanto, Soerjono. Faktor-Faktor Yang Mempengaruhi Penegakan Hukum. Jakarta: Jakarta: Raja Grafindo Persada, 1993.

Soekanto, Soerjono, and Sri Mamudji. Penelitian Hukum Normatif, Suatu Tinjauan Singkat. Jakarta: Raja Grafindo Persada. Jakarta: Rajawali Pers, 2015.

Soemitro, Ronny Hanitijo. Metodologi Penelitian Hukum Dan Jurimetri. Jakarta: Ghalia Indonesia, 1990.

Sunaryo, Sidik. Kapita Selekta Sistem Peradilan Pidana. Malang: Universitas Muhammadiyah Malang Press, 2004.

Tahamata, Lucia Charlota Octovina. “Penegakan Hukum Diwilayah Laut Maluku Oleh Lantamal IX Ambon." Balobe Law Journal 1, no. 1 (2021): 17-24.

Ubwarin, Erwin. “Penegakan Hukum Yang Dilakukan Oleh Polair Polda Maluku." Jurnal Muara Ilmu Sosial, Humaniora, Dan Seni 2, no. 1 (2018): 44-51.

Wasisto, Gentur. "Kewenangan BAKAMLA Dalam Penegakan Hukum Tindak Pidana Tertentu Di Laut Berdasarkan UU No. 32 Tahun 2014 Tentang Kelautan." Jurnal Hukum, 2015, 1-23.

Wiratama, Heru. "Kewenangan TNI AL Selaku Penyidik Tindak Pidana Dilaut Dalam Mengamankan Perairan Indonesia." Jurnal Hukum, 2015, 1-30.

Anwar, Syaiful. "Membangun Keamanan Maritim Indonesia Dalam Analisa Kepentingan, Ancaman, Dan Kekuatan Laut." Jurnal Pertahanan E Bela Negara 6, no. 3 (2018): 69-90.

Atmasasmita, Romli. Tindak Pidana Narkotika Transnasional Dalam Sistem Hukum Pidana Indonesia. Bandung: Citra Aditya Bakti, 1997.

Damian, Eddy. Kapita Selekta Hukum Internasional. Bandung: Alumni, 1991.

Hadju, Zainal Abdul Aziz. "Analisis UNCLOS 1982 Terkait Permasalahan Yurisdiksi Negara Dan Penegakan Hukum Atas Kapal Berbendera Negara Asing." SASI 27, no. 1 (2021): 12-23. https:/ / doi.org/10.47268/ sasi.v27i1.254.

Hananto, Akhyari. “Dikukuhkan Di New York Agustus Ini, Inilah Jumlah Resmi Pulau Di Indonesia." $\quad$ www.goodnewsfromindonesia.id, 2017. https:/ / www.goodnewsfromindonesia.id/2017/08/19/dikukuhkan-di-new-york agustus-ini-inilah-jumlah-resmi-pulau-di-indonesia.

Ibrahim, Johnny. Teori Dan Metode Penelitian Hukum Normatif. Malang: Malang: Bayu Media Publishing, 2006.

Kusumaatmadja, Mochtar, and Etty R Agoes. Pengantar Hukum Internasional. Bandung: 
Alumni, 2015.

Marzuki, Peter Mahmud. Penelitian Hukum,. Jakarta: Kencana, 2016. https://doi.org/340.072.

Rahardjo, Satjipto. Sosiologi Hukum: Perkembangan Metode Dan Pilihan Masalah. Yogyakarta: Genta Publishing, 2010.

Ramdhan, Muhammad, and Taslim Arifin. “Aplikasi Sistem Informasi Geografis Dalam Penilaian Proporsi Luas Laut Indonesia." Jurnal Ilmiah Geomatik 19, no. 2 (2013): 14146.

Rumata, Jamaludin. "Kepulauan Maluku Dalam Geopolitik Regional." kompastimur.com, 2018. https:/ / www.kompastimur.com/2018/10/kepulauan-maluku-dalamgeopolitik.html.

Samiaji, Ranu. "Harmonisasi Kewenangan Lembaga Negara Dalam Menanggulangi Tindak Pidana Illegal Fishing Di Perairan Indonesia." Jurnal Hukum, 2015, 1-22.

Santoso, M Iman. "Kedaulatan Dan Yurisdiksi Negara DalamSudut Pandang Keimigrasian." Binamulia Hukum 7, no. 1 (2018): 1-16.

Shant, Dellyana. Konsep Penegakan Hukum. Yogyakarta: Sinar Grafika, 1988.

Simma, Bruno, Daniel Erasmus Khan, Georg Nolte, and Andreas Paulus. The Charter of the United Nations: A Commentary. Berlin: Oxford University Press, 1995.

Soekanto, Soerjono. Faktor-Faktor Yang Mempengaruhi Penegakan Hukum. Jakarta: Jakarta: Raja Grafindo Persada, 1993.

Soekanto, Soerjono, and Sri Mamudji. Penelitian Hukum Normatif, Suatu Tinjauan Singkat. Jakarta: Raja Grafindo Persada. Jakarta: Rajawali Pers, 2015.

Soemitro, Ronny Hanitijo. Metodologi Penelitian Hukum Dan Jurimetri. Jakarta: Ghalia Indonesia, 1990.

Sondakh, Bernard Kent. "Pengamanan Wilayah Laut Indonesia." Jurnal Hukum $\mathcal{E}$ Pembangunan 33, no. 1 (2003): 76-88.

Sunaryo, Sidik. Kapita Selekta Sistem Peradilan Pidana. Malang: Universitas Muhammadiyah Malang Press, 2004.

Tahamata, Lucia Charlota Octovina. “Penegakan Hukum Diwilayah Laut Maluku Oleh Lantamal IX Ambon." Balobe Law Journal 1, no. 1 (2021): 17-24.

Ubwarin, Erwin. "Penegakan Hukum Yang Dilakukan Oleh Polair Polda Maluku." Jurnal Muara Ilmu Sosial, Humaniora, Dan Seni 2, no. 1 (2018): 44-51.

Wasisto, Gentur. "Kewenangan BAKAMLA Dalam Penegakan Hukum Tindak Pidana Tertentu Di Laut Berdasarkan UU No. 32 Tahun 2014 Tentang Kelautan." Jurnal Hukum, 2015, 1-23.

Wiratama, Heru. "Kewenangan TNI AL Selaku Penyidik Tindak Pidana Dilaut Dalam Mengamankan Perairan Indonesia." Jurnal Hukum, 2015, 1-30. 